\title{
Primary Cutaneous Lymphoma TNM Finding v8
}

National Cancer Institute

\section{Source}

National Cancer Institute. Primary Cutaneous Lymphoma TNM Finding v8. NCI

Thesaurus. Code C141303.

A finding about one or more characteristics of primary cutaneous lymphoma [mycosis fungoides and Sezary syndrome (MF/SS) and primary cutaneous B-cell/T-cell (nonMF/SS) lymphomas], following the rules of the TNM v8 classification system. Both MF/SS and primary cutaneous B-cell/T-cell (non-MF/SS) lymphomas have TNM classification systems. MF/SS has a formal prognostic stage groups system proposed by the International Society for Cutaneous Lymphomas (ISCL) and the cutaneous lymphoma task force of the European Organisation for Research and Treatment of Cancer (EORTC). There is no prognostic stage groups system for primary cutaneous B-cell/Tcell (non-MF/SS) lymphomas at this time. This classification system does not apply to eyelid skin lymphomas (are staged according to the classification for ocular adnexal lymphoma). (from AJCC 8th Ed.) 